\title{
Review: Developments of Photovoltaic/thermal (PVT) Collectors
}

\author{
Qixian Wang ${ }^{1, *}$ \\ ${ }^{1}$ University of California at Santa Barbara, Goleta, California, 93117, US
}

\begin{abstract}
The alarming energy concerns have stimulated a transition of energy sources to a more sustainable way. Among all of the green energy sources, solar is the most promising one. Recently, a new application called photovoltaic/thermal panels that harvest both long-wavelength and short-wavelength radiations has been gaining attention. Evidence shows that the combined system is more efficient than the two separate systems. Its wide range of applications can significantly promote the transition to a cleaner energy source. This work provides an introduction to the PV/T panels and examines the improvement possibilities of the $\mathrm{PV} / \mathrm{T}$ panels. Challenges and suggestions for future researches will be discussed.
\end{abstract}

\section{INTRODUCTION}

The total global energy consumption rose to an alarming number of 173340TWh in 2019, and is still increasing. Among the $173340 \mathrm{TWh}, 84.3 \%$ are derived from fossil fuel [1]. The global energy demand increased by less than half of the rate in 2018, which is largely due to slowed economic growth and milder climate [2]. However, energy consumption was still growing in developing countries, especially in China, releasing a tremendous amount of carbon dioxide into the atmosphere and resulting in global warming. Consequently, we need a fast transition to low carbon energy sources like renewable energies (solar, nuclear, wind, water). Solar energy is one of the most promising options. The long wavelength solar radiation, as known as solar thermal energy, and the photovoltaic solar energy, can be the most important energy suppliers for the world if they are developed in a scientific manner.

Although solar PV electricity generation has grown by a factor of 22 percent from 2018 to 2019 , it still provides only a small section of $2.7 \%$ of the electricity supply [2]. There is still much room for improvement. With the technical advance, increased installment, and new policies in favor of photovoltaic energy, PV will grow fast and eventually become a major energy source in the world. For example, the European Commission has announced their plan of achieving a climate-neutral economy by 2050 [3]; China has been encouraging the growth of solar by subsidizing the price of electricity generated from photovoltaic panels. As predicted by International Energy Agency (IEA), the global solar PV generation will show a leap between 2019 and 2030, an increase from $720 \mathrm{TWh}$ to $3268 \mathrm{TWh}$. Solar thermal power generation systems collect and concentrate the sunlight to generate heat, also known as concentrating solar power
(CSP). This heat is either used domestically or converted to electricity. Solar thermal power systems have trackers that follow the sun's position throughout the day to guarantee maximum power output [4]. CSP generation increased by approximately $34 \%$ in 2019 , but it still only provides 15.6TWh of energy. To achieve a sustainable developing scenario, the total solar thermal energy production needs to reach $183.8 \mathrm{TWh}$ by 2030 , which requires an annual increase of about $24 \%$. The hybrid photovoltaic thermal systems combine the solar photovoltaic and thermal collectors together to promote overall efficiency. The combined system can take advantage of both energy sources at the same time [2].

A hybrid energy system uses two or more energy sources to achieve higher overall efficiency. Photovoltaic thermal solar collectors are perfect examples of hybrid energy systems. Conventional solar panels harvest only the short wavelength radiation from sunlight to produce current, achieving an efficiency from $6 \%$ to $18 \%$ [5]. However, the long-wavelength radiation from the sun converts into thermal energy and thus heat up the solar panels. At the same time, the waste heat on photovoltaic panels will result in hot spots. Hot spots are especially detrimental to the PV panels since they will reduce their lifespan significantly. To maintain the solar panels at optimum efficiency and fully utilize the long wavelength radiation of the sun, the heat on solar panels is desired to be removed from the photovoltaic layer. The photovoltaic thermal collectors are thus designed by combining photovoltaic cells with heat-removing components. This allowed the solar panels to reach their maximum efficiency by reducing the temperature and, in the meantime, harvested the extra thermal energy. The PV/T technology works extraordinarily with households since the thermal energy can be directly used for heating. During these years, PVT panels have incorporated flatplate photovoltaic solar systems, heat pipes with various

* Corresponding author: qixianwang@ucsb.edu 
heat transporters like water, air and refrigerants. However, since the PV/T system is a relatively new technology, its technical difficulties, economic feasibility and applicational problems are not sufficiently discussed. This article provides a review work that unravels the points above. This work is intended to help future researchers to have a basic understanding of the PV/T system and identify future research directions.

\section{CLASSIFICATION OF PHOTOVOLTAIC THERMAL COLLECTORS}

In response to different environmental conditions, economic perspectives and technical appliances, photovoltaic thermal collectors are classified into many categories. Structurally, the PVT collectors can be classified as non-concentrated type and concentrated type. In terms of heat extraction, the PVT collectors can be classified into forced circulation or natural circulation. According to different types of coolants used, PV/T collectors are characterized into air-based $\mathrm{PV} / \mathrm{T}$ collector, water-based PV/T collector, and refrigerant-based PV/T collector [6]. The advantages and disadvantages of different types of coolants will be discussed, and an innovative heat-pipe $\mathrm{PV} / \mathrm{T}$ collector will be introduced.

\subsection{Air-based PV/T collectors}

The most commonly applied method for cooling photovoltaic panels is moving air [7]. Normally, an airbased PV/T system consists of a PV panel, insulation, and one or more glass covers on the top. There are various types of air-based PV/T models: (1) conventional airbased PV/T system or back-pass air-based PV/T model; (2)double-pass with inlet air from channel above a PV panel; (3) single-pass parallel PVT system; (4) single-pass with a channel above a PV panel, and (5) double-pass with inlet air from channel above a PV panel [8]. In the categories above, air could be delivered from the top, bottom, or both sides of the solar panels.

Compared to conventional solar panels, air-based $\mathrm{PV} / \mathrm{T}$ collectors have achieved great improvement in harvesting efficiency of both electricity and thermal energy. Fudholi et al. conducted a research in 2018, presenting statistical values of PVT collectors with a thermal efficiency ranging from $21.3 \%-82.9 \%$ and electrical efficiency of $9.87 \%-11.34 \%$. Overall, the average energy efficiency is $66.73 \%$ in experimental studies, which is significantly higher than the $10.7 \%$ of the Photovoltaic panel alone [9]. The air-based PV/T models are usually for users demanding hot air, space heating, or drying of herbs. However, since the thermal density of air is relatively low, the efficiency could be significantly diminished when the thermal energy needs to be transferred very high.

\subsection{Water-based PV/T collector}

Water-based PV/T systems use water as the medium of heat transfer. Generally, they consist of solar panels, absorber collectors, insulation, and glass cover. According to finished research, water-based $\mathrm{PV} / \mathrm{T}$ models are generally categorized into 3 types: (1) natural flow, (2) hybrid system, and (3) forced flow [10]. The most common type is the forced flow PV/T system because the flow rate of water can be controlled in this type. Water is forced to flow through the absorber along with the solar panel, carrying the thermal energy away, thus increasing the electrical efficiency. There are different types of absorbers in water-based PV/T models. The system is closed where water enters hollow tubes and is heated continuously until it finally flows into a water tank. Figure 1 has shown 7 different types. The highest thermal efficiency is achieved in the spiral flow design at 50.12\%, and the lowest is achieved in serpentine design at $32.35 \%$. 


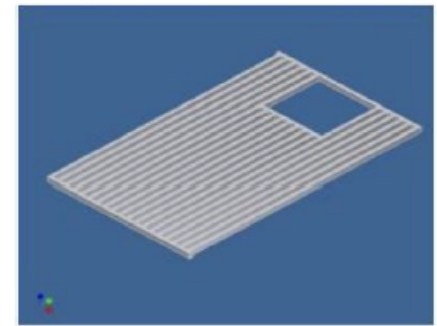

(a)

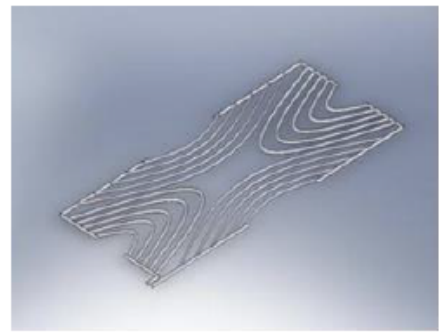

(d)

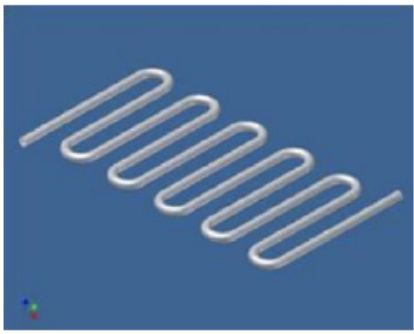

(b)

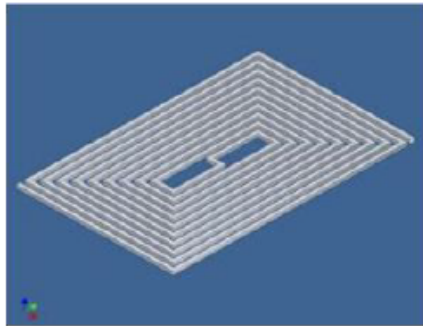

(e)

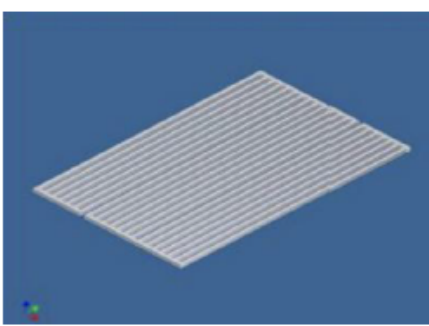

(g)

g)

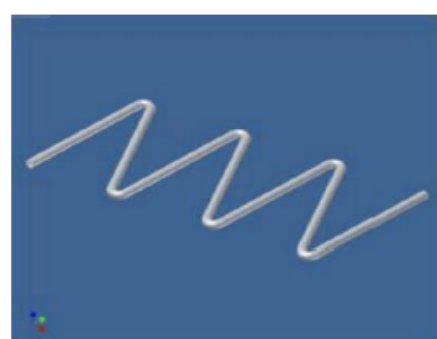

(c)

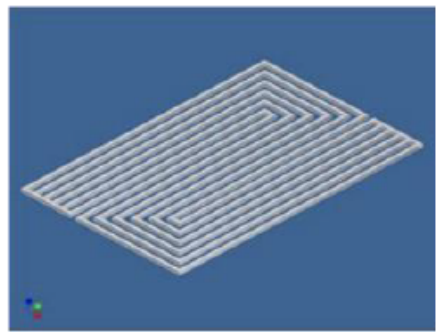

(f)

Figure 1. Different types of absorbers in water-based PV/T collector (a) direct flow design, (b)Oscillatory Flow Design (c)Serpentine Flow Design, (d)Parallel-Serpentine Flow Design, (e)Spiral flow design (f)Web Flow Design (g)modified serpentine parallel-flow design [11]

Compared to air-based PV/T systems, water-based PV/T systems could achieve higher overall efficiency due to water's higher thermal density. Matuska et al. conducted a study on the efficiency of the water-based $\mathrm{PV} / \mathrm{T}$ system in China. In the experiment, both electrical and thermal efficiencies were measured under certain mass flow rates. When the heated water flow under the unit heat-collection area was more than 80 kilograms per square meter, the diurnal electrical efficiency was about $10.15 \%$, and the diurnal thermal efficiency was about $45 \%$ [12].

\subsection{Refrigerant-based PV/T collector}

Recently, refrigerant-based PV/T collectors have attracted increased attention. Huan-Liang Tsai had investigated the refrigerant-based PVT-assisted heat pump water heating system in 2013. The model consists of a PV/T evaporator array, a compressor, a condenser, and an electronic expansion valve. The part that differentiates from other types of $\mathrm{PV} / \mathrm{T}$ collectors is the $\mathrm{PV} / \mathrm{T}$ evaporator array in which refrigerant R-134a flows. While flowing through the PV/T evaporator, R-134a went through a phase change and is vaporized to carry the heat away. Then the refrigerant is compressed in the compressor, and the extra heat is rejected into the water in the condenser. Thus R134a finishes a thermal cycle and is ready to enter the evaporator again for another round. The heat pump is directly powered by the electricity harvested by the PV/T model. As a result, there is no fossil fuel burning throughout the entire process [13].

Since the refrigerants usually evaporate at a low temperature of 0-20 degrees celsius, the PV cells would most likely be maintained at the same temperature, resulting in significant improvements in the electrical efficiency of the PV panels.

\subsection{Heat pipe PV/T collectors}

Even though PV panels work better at low temperatures, freezing water in PV/T systems may lead to failure. This approach permits heat transfers in the fluid at almost zero energy loss. Figure 2 demonstrates a brief overview of the heat pipe PV/T collector. Compared to conventional flat plate PV/T collectors, HP-PVT has advantages like freeze protection, lower pumping power required, and higher efficiency. In a heat pipe, PV/T collectors water is heated up when receiving radiation from the sun and runs through the condenser sections of the heat pipe. Then it circulates to the storage tank and starts another cycle [14]. 


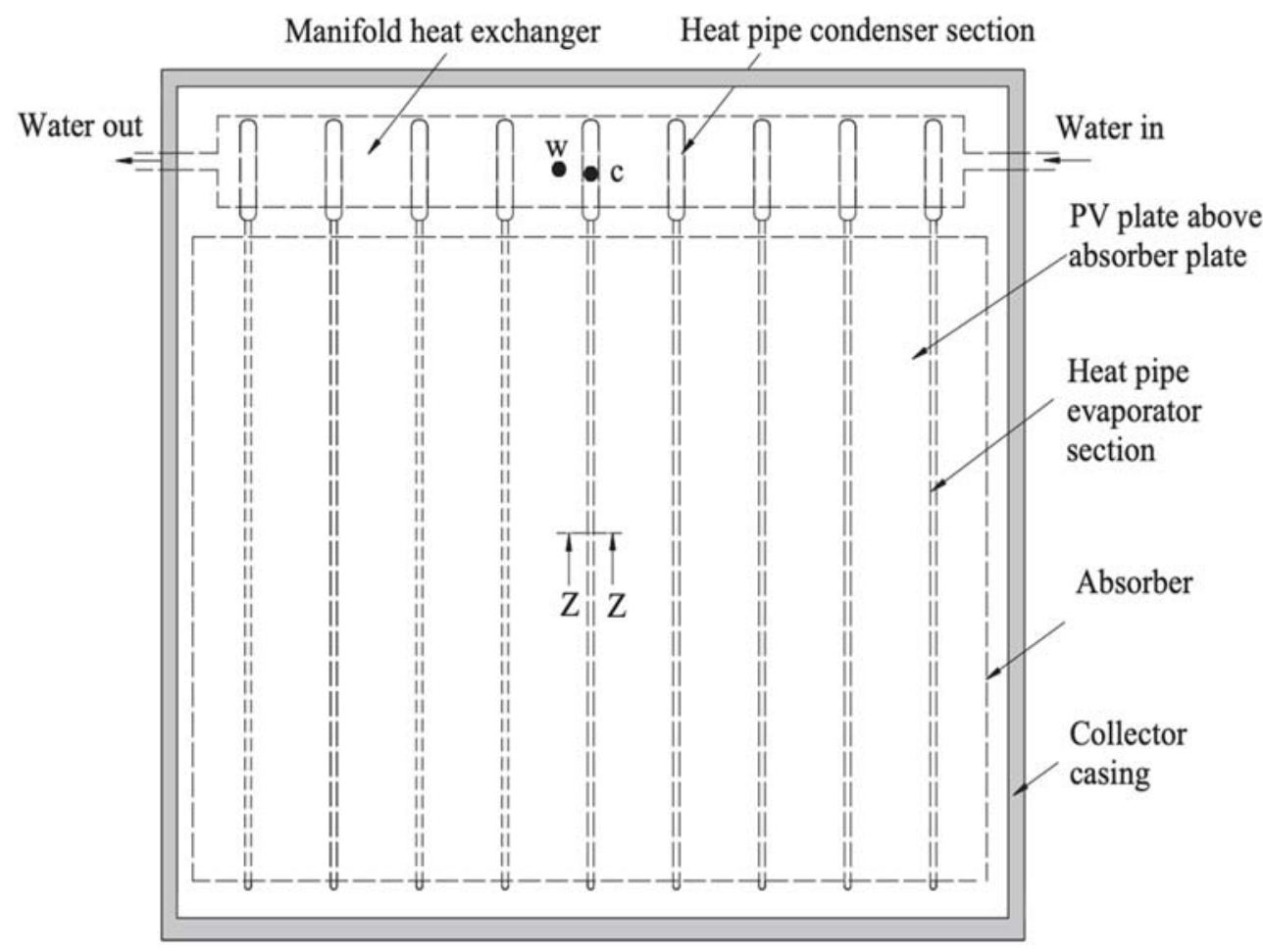

Figure 2. An illustration of heat-pipe PV/T collector [14]

\section{APPLICATION OF THE PHOTOVOLTAIC THERMAL COLLECTORS}

The major output of PV/T collectors is thermal energy and electric energy. Electric energy is usually provided for domestic use. Thermal energy, on the other hand, can be used in various ways like heating water, temperature control in buildings, dehumidification and desalination.

\subsection{Application of PV/T collector in water heating}

$\mathrm{Li}$ et al. conducted a study on the performance of photovoltaic/thermal water heating systems. In his research, he compared the performance of PV/T systems with direct-coupled photovoltaic pumps, traditional DC pumps or natural flow. The study results indicate that the photovoltaic/thermal system with a photovoltaic pump outperformed the natural flow pattern a little but was significantly more efficient than the conventional DC pump, reaching an overall energy efficiency of $69.63 \%$ and exergy efficiency of $12.84 \%$. The photovoltaic pump is efficient because it automatically adjusts the flow rate of water with the solar irradiation received. When the solar irradiation is high, the flow rate will increase, and hence the convection will increase; when the solar irradiation is low, the flow rate will decrease, reducing the heat loss [15].

Aneta Hazi et al. proposed a study to assess the feasibility of using photovoltaic/thermal systems for water heating in the industry. For this purpose, a mathematical model simulating the climate condition in Romania is built. The numerical analysis suggests that the hours of solar irradiation, the average temperature of the location, and the water source are crucial to the energy parameter and economic feasibility. Generally, the payback period increases in areas with low solar irradiation hours and temperature when using underground water but decreases when using surface water. Theoretically, in the simulation, the payback time is shorter than their lifetime, making it economically feasible [16].

Chow et al. conducted a study in 2007 to study the performance of a centralized photovoltaic/thermal wall system when preheating water. PV/T wall systems are installed on a southwest vertical facade in Hongkong. During late summer, the thermal efficiency was $38.9 \%$, and the corresponding electric efficiency was $8.56 \%$. The system can work as a good alternative that the thermal loads of the building can be much reduced in both summer and winter in Hong Kong [17].

\subsection{Application of PV/T collector in temperature control}

Bambrook et al. investigated the experimental efficiency of air-based photovoltaic/thermal collectors. An unglazed, single pass open loop PV/T air system was installed toward the north with a tilt angle of 34 degrees in Sydney. Six 110WP borderless PV modules were adopted by the system. It was shown that a larger flow rate of air could promote both thermal efficiency and electrical efficiency. To provide a large air flow rate at minimum energy consumption, large ducts were used to reduce pressure loss, and low energy-demanding fans with high flow rates were carefully selected. The results have shown the thermal efficiencies between $28-55 \%$ and electrical PV efficiencies between 10.6-12.2\%. The PV output was in access to the energy required to power the fans, so the model was technically and economically feasible [18]. 
Mohammed Alobaid et al. evaluated the recent advances in the combination of an absorption chiller and photovoltaic thermal collectors. Their review presented the efficiency and evaluation indicators with experimental and computational data. Compared to traditional vaporcompression air conditioning, the combination system saved $50 \%$ of primary energy and produced $10-35 \%$ more electrical energy. However, electrical efficiency, thermal efficiency, and the overall COP (coefficient of performance) are greatly influenced by the environment and solar irradiation. Moreover, the economic perspectives of commercial adoption, including the running cost, price of electricity and the urgency of a cooling system, need to be further investigated [19].

\subsection{Application of PV/T collector in dehumidification}

Tiwari et al. researched the performance of $\mathrm{N}$-fully covered semitransparent photovoltaic thermal-compound parabolic concentrator (PVT-CPC) for vapor absorption refrigeration. Its performance is also compared with photovoltaic thermal-flat plate absorber (PVT-FPC), conventional flat plate-compound parabolic concentrator, and conventional flat-plate absorber. The process is carried out by numerical simulation on MATLAB using the climate condition in New Delhi. The study concluded that both PV/T systems, the PVT-CPC and PVT-FPC systems, are self-sustained to vapor absorption refrigeration systems. The research also strongly pointed that the size of both systems needs to be optimised according to the capacity of vapor absorption refrigeration [20].

Mohamed et al. conducted a study on the drying of potato chips using air-based photovoltaic/thermal collectors. The system dried potato chips under different treatments and operating conditions in the college of Agriculture and food science, King Faisal University of Saudi Arabia. The study concluded that attaching a small DC fan to the air-based PV/T system to control the airflow will improve the drying performance. The tunnel dryer performance was promoted using the above system. The dried chips' quality and stability are also improved since it reduces moisture content and minimizes microbiological activities [21].

\subsection{Application of PV/T collector in desalination}

Chen et al. investigated the performance of a flash tank integrated with a low concentration PV/T system (FT-
LCPVT) in desalination. In one working cycle, salted water is first preheated by the LCPVT collector and then further heated by a solar thermal collector. Heated water will be vaporized in the flash tank and finally condensed as clean water in the condenser. The experiment was operated under a pressure of $20 \mathrm{Kpa}$ and temperature in the flash tank of 90 degrees celsius. The system is fully selfsustained. The maximum electrical and freshwater output are $447.55 \mathrm{~W}$ and $23.65 \mathrm{~L}$, respectively [22].

Naroei et al. numerically and experimentally evaluated the efficiency of connecting stepped solar to a water-based photovoltaic/thermal collector. A transient thermal model, including the PV/T water collector, saline water, flat plate absorber, and glass cover, was analyzed and further validated by the experimental model. The optimum output is achieved when the mass flow rate is $0.068 \mathrm{~kg} / \mathrm{min}$. The results indicated that attaching a water-based $\mathrm{PV} / \mathrm{T}$ collector to the stepped solar still increases the efficiency more than 2 times the original value and improves the water output by $20 \%$. The PV module in the $\mathrm{PV} / \mathrm{T}$ collector provides $1.06 \mathrm{KW}$ per day of electricity in addition to the power needed for pumping [23].

\subsection{Integration of PV/T collector with office buildings}

Powering a building at zero external energy consumption to satisfy the need for electricity and regulating the temperature has been identified as a future building design trend. Due to space limitations for the installment of energy collectors, the $\mathrm{PV} / \mathrm{T}$ hybrid system is very promising. Reiner Braun et al. investigated the technical and economic feasibility of using a PV/T collector to power an office building.

To test the applicability, models were built in three very different climate regions: Moscow, representing the cold climate zone; Stuggart, representing the moderate central Europe climate; Dubai, representing hot desert climate. In the simulation, the PV/T was utilized as both heat source and heat sink for a reversible heat pump. The building is designed according to the IEA SHC task 32 with parameters shown in Figure 3 and Table1. The electricity demand is calculated according to the Swiss guideline SIA 380/4 ("Electrical Energy in Building Construction"). Since the building is an office, the energy demand is reduced to $20 \%$ at night and during the weekend. 


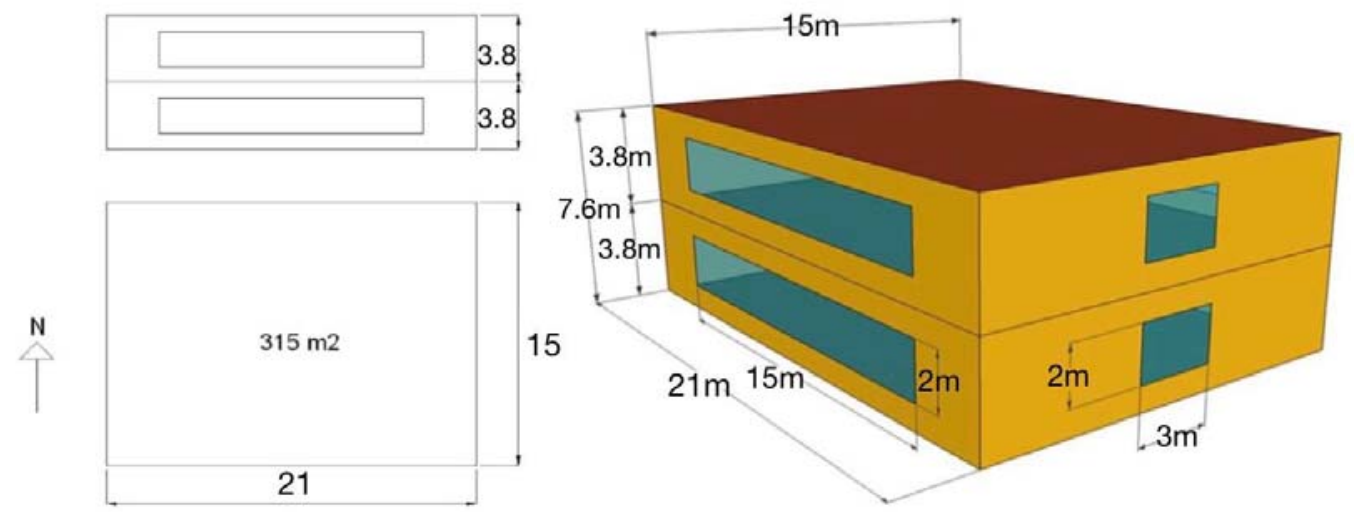

Figure 3. Floor plan and north-south view of the building model based on the IEA Task 38 (left) and 3D model (right) [24]

Table 1. Building geometry parameters [24]

\begin{tabular}{llc}
\hline parameter & value & unit \\
\hline storey/thermal zones & 2 & - \\
Total gross floor area & 630 & $\mathrm{~m}^{2}$ \\
gross/net floor height & $3.8 / 3.2 \mathrm{~m}$ & $\mathrm{~m}$ \\
Net area per floor & 273.6 & $\mathrm{~m}^{2}$ \\
Total air volume & 1751 & $\mathrm{~m}^{3}$ \\
Modelled building orientation & Along the east west axis, oriented to south & - \\
Glazing ratio for the north and south facades & 38 & $\%$ \\
Glazing ratio for the east facade & 10 & $\%$ \\
West facade opaque & 0 & $\%$ \\
\hline
\end{tabular}

The conclusion is that $\mathrm{PV} / \mathrm{T}$ collectors are good energy collectors when integrated with buildings to provide electricity, ventilation and air-conditioning, especially in non-residential buildings like offices. Most importantly, the $\mathrm{PV} / \mathrm{T}$ system is compatible with different climate conditions and building standards, meaning it can be an option for buildings worldwide. However, the economic feasibility and payback time varies according to the domestic policies. For example, in Moscow and Dubai, only a small $10 \mathrm{~m} 2 \mathrm{PV} / \mathrm{T}$ board is economically feasible, while in Stuttgart, the area is up to $100 \mathrm{~m} 2$. The larger area means not only less carbon emission but also greater cost efficiency [24].

\section{IMPROVEMENTS ON PV/T COLLECTORS}

Ever since the first photovoltaic thermal collector was proposed by Martin Wolf in 1976, it has been constantly developed over the years [25]. The optical and thermal structure, as well as the working fluid in the $\mathrm{PV} / \mathrm{T}$ collectors, have been revolutionized. The following section provides a review of some major improvements on the PV/T collectors.

\subsection{Structure improvements}

The structure and material of the $\mathrm{PV} / \mathrm{T}$ collectors can significantly affect their efficiencies. Currently, most hybrid PV/T collectors consist of separated photovoltaic and thermal systems juxtaposing to the other. Though this may employ the advantages of the PV/T system to some extent, the structure can be further improved to achieve optimum efficiency.

Unlike normal Photovoltaic modules that have solar cells, EVA layers and a Tedlar-Polyester-Tedlar layer laminated on a glass plane, $\mathrm{PV} / \mathrm{T}$ modules can have them laminated on a coated flat plate heat exchanger. In this case, the glass plane is not a necessity as a protective cover since the heat exchanger can provide the rigidity required. The protective layer can be replaced by films with low reflection rates or encapsulative materials. Before reaching the solar cell, the lights have to travel through several layers like air, EVA and glass. Each layer has its own refraction rate - the higher the total refraction, the lower amount of light that can touch the solar cell. Consequently, by replacing the glass (refraction rate of 1.517) with a film with a lower refraction rate, more photons can be transmitted to the solar cell. 
Patrick et al. performed experiments on a theoretical model and the according prototype. In his models, he employed not only different structures but also different materials of Encapsulant. Encapsulant is the layer between the solar cell and the front cover that may absorb the photons traveling through. Three series with different choices of front cover and encapsulants are tested. The experimental results agree with the theoretical model that a $2 \mathrm{~mA} / \mathrm{cm} 2 \quad$ increase in electrical output is observed using BI sample [26].

\subsection{Innovative coolant selection}

Air, water, and refrigerants are the most common coolants for PV/T collectors. Recently, the effect of adding nanoparticles into the water to promote the efficiency of PV/T collectors has been investigated. Joo Hee Lee et al. from Kangwon National University conducted a study using nanofluids $(\mathrm{CuO} /$ water, $\mathrm{Al} 2 \mathrm{O} 3 /$ water $)$ as the working fluid in flat-plate photovoltaic thermal collectors.

In this study, 10 mono crystalline solar cells are connected in series to act as the PV module. Copper pipes are installed under the PV module to work as the absorbing tube that takes away the heat from the PV module. A pump and a flow meter control the flow rate of the nanofluids to find the optimum efficiency. The nanofluids are prepared by adding metallic particles into distilled water at $0.05 \mathrm{wt} . \%$. After the nanoparticles are added, the solution is stirred for 30 minutes and dispersed for 90 minutes.

Experiments using water and nanofluids as the heat transport medium were conducted and results are presented. In normal water-based $\mathrm{PV} / \mathrm{T}$ collectors, the maximum efficiency is achieved at a flow rate of $3 \mathrm{~L} / \mathrm{min}$. At this flow-rate, the thermal and electrical efficiency of the water-based PV/T are $23.58 \%$ and $12.8 \%$, respectively. When using nanofluids as the working fluid, the thermal efficiency increased by $21.3 \%$ in $\mathrm{CuO} /$ water solution and $15.14 \%$ in $\mathrm{Al} 2 \mathrm{O} 3 /$ water solution. The thermal improvement is significant. However, the difference in electrical conductivity is small because the temperature decrease is small and the area of the solar cell is small. In order to further investigate the effectiveness of nanofluids, researchers should apply nanofluids $\mathrm{PV} / \mathrm{T}$ systems in higher climate temperatures to achieve a greater temperature reduction [27].

\section{SUGGESTION FOR FUTURE RESEARCH}

The various PV/T systems mentioned above have advantages in their own way but are flawed in the same manner. Their high price prohibited them from a wide application. To reduce the cost, a new prototype of PV/T system replaces the ordinary packaging material with cheap non-imaging optics. The sheet and tube heat exchanger are also replaced with aluminum mini channels. Its efficiency was tested to be comparable to traditional $\mathrm{PV} / \mathrm{T}$ systems, and it has a lower cost of $\$ 81 / \mathrm{m} 2$. This provides a possibility for a more economically feasible PV/T option [28]. However, before wide range installation, its acclaimed advantage and stability need further validation through experiments. At the same time, other types of PV/T improvements should also be considered.

Among the four types of traditional PV/T mentioned above, air-based and water-based PV/T are relatively fully developed; hence there is limited room for further improvement. The refrigerant and heat-pipe $\mathrm{PV} / \mathrm{T}$ are newly developed and remain a large space to investigate their engineering configuration.

\section{CONCLUSION}

$\mathrm{PV} / \mathrm{T}$ collectors absorb solar photovoltaic and thermal energies at the same time to promote overall efficiency. This study briefly introduced the categories of PV/T collectors. Compared to other fields of applications of $\mathrm{PV} / \mathrm{T}$ systems, it can be concluded that the PV/T collectors are very efficient when combined with buildings. This study shows that $\mathrm{PV} / \mathrm{T}$ systems can be improved by using cheaper materials and replacing their coolant with innovative nanofluids. The review provides some perspectives for future researchers in terms of basic concepts of PV/T collector, applications, and possibilities of further developments. This will contribute to the improvements of $\mathrm{PV} / \mathrm{T}$ systems and a transition toward the vast use of renewable energies.

\section{REFERENCE}

1. Hannah Ritchie (2014) - "Energy". Published online at OurWorldInData.org. Retrieved from: 'https://ourworldindata.org/energy' [Online Resource]

2. Iea. "Global Energy Review 2019 - Analysis." IEA, www.iea.org/reports/global-energy-review-2019.

3. Parnell, John. "Europe's Thinking Shifts on Supporting Renewables as Part of Green Recovery Package." Europe's Thinking Shifts on Supporting Renewables as Part of Green Recovery Package | Greentech Media, Greentech Media, 23 Sept. 2020,

4. Iea. "Solar - Fuels \& Technologies." IEA, www.iea.org/fuels-and-technologies/solar.

5. Messenger RA, Ventre J. Photovoltaic system engineering. 2nd ed. Florida (USA): CRC Press; 2003. pp. 54-55.

6. Sandeep S. Joshi, Ashwinkumar S. Dhoble, Photovoltaic -Thermal systems (PVT): Technology review and future trends, Renewable and Sustainable Energy Reviews, Volume 92, 2018, Pages 848-882, ISSN 1364-0321.

7. Xudong Zhao, Xingxing Zhang, Saffa B. Riffat, Yaxin $\mathrm{Su}$, Theoretical study of the performance of a novel PV/e roof module for heat pump operation, Energy Conversion and Management, Volume 52, Issue 1, 2011, Pages 603-614, ISSN 0196-8904,

8. Rukman, Nurul Shahirah Binti, et al. "Electrical and thermal efficiency of air-based photovoltaic thermal (PVT) systems: an overview." Indonesian Journal of 
Electrical Engineering and Computer Science 14.3 (2019): 1134-1140.

9. Fudholi A, Zohri M, Jin GL, Ibrahim A, Yen $\mathrm{CH}$, Othman MY, Ruslan MH, Sopian K (2018), Energy and exergy analysis of pho-tovoltaic thermal collector with $\nabla$-groove. Solar Energy 159, 742-50.

10. Rukman, Nurul Shahirah Binti, et al. "Energy and exergy efficiency of water-based photovoltaic thermal (PVT) systems: an overview." International Journal of Power Electronics and Drive Systems (IJPEDS) 10.2 (2019): 987-994.

11. Ibrahim, Adnan \& Othman, Mohd \& Ruslan, M.H. \& Alghoul, Mohammad \& Yahya, Mohd \& Zaharim, And \& Sopian, Kamaruzzaman. (2009). Performance of photovoltaic thermal collector (PVT) with different absorbers design. WSEAS Transactions on Environment and Development. 5.

12. Matuska, Tomas. "Performance and economic analysis of hybrid PVT collectors in solar DHW system." Energy Procedia 48 (2014): 150-156.

13. Huan-Liang Tsai, Modeling and validation of refrigerant-based PVT-assisted heat pump water heating (PVTA-HPWH) system, Solar Energy, Volume 122, 2015, Pages 36-47, ISSN0038-092X

14. Hui Long, Tin-Tai Chow, Jie Ji, Building-integrated heat pipe photovoltaic/thermal system for use in Hong Kong, Solar Energy, Volume 155, 2017, Pages 1084-1091, ISSN 0038-092X,

15. Li, Guiqiang. (2019). Performance comparison of photovoltaic/thermal solar water heating systems with direct-coupled photovoltaic pump, traditional pump and natural circulation. Renewable Energy. 136. 10.1016/j.renene.2019.01.028.

16. Aneta Hazi, Gheorghe Hazi, Roxana Grigore, Sorin Vernica, Opportunity to use PVT systems for water heating in industry, Applied Thermal Engineering, Volume 63, Issue 1, 2014, Pages 151-157, ISSN 1359-4311,

17. T.T. Chow, W. He, J. Ji, An experimental study of façade-integrated photovoltaic/water-heating system, Applied Thermal Engineering, Volume 27, Issue 1, 2007, Pages 37-45, ISSN 1359-4311,

18. S.M. Bambrook, A.B. Sproul, Maximising the energy output of a PVT air system, Solar Energy, Volume 86, Issue 6, 2012, Pages 1857-1871, ISSN 0038-092X,

19. Mohammad Alobaid, Ben Hughes, John Kaiser Calautit, Dominic O'Connor, Andrew Heyes, A review of solar driven absorption cooling with photovoltaic thermal systems, Renewable and Sustainable Energy Reviews, Volume 76, 2017, Pages 728-742, ISSN 1364-0321.
20. Tiwari, G.N., Meraj, M., Khan, M.E., 2018b. Exergy analysis of N-photovoltaic thermal compound parabolic concentrator (N-PVT-CPC) collector for constant collection temperature for vapor absorption refrigeration (VAR) system. Sol. Energy 173, A. Herez, et al. Solar Energy 207 (2020) 1321-1347 1032-1042.

21. Mohamed A. Eltawil, Mostafa M. Azam, Abdulrahman O. Alghannam, Solar PV powered mixed-mode tunnel dryer for drying potato chips, Renewable Energy, Volume 116, Part A, 2018, Pages 594-605, ISSN 0960-1481, https://doi.org/10.1016/j.renene.2017.10.007.

22. Chen Haiping, Guo Xinxin, Zhang Heng, Liu Yang, Liu Haowen, Bu Yuegang, Experimental study on a flash tank integrated with low concentrating PV/T (FT-LCPVT) hybrid system for desalination, Applied Thermal Engineering, Volume 159, 2019, 113874, ISSN 1359-4311, https://doi.org/10.1016/j.applthermaleng.2019.11387 4.

23. Mehrnaz Naroei, Faramarz Sarhaddi, Fatemeh Sobhnamayan, Efficiency of a photovoltaic thermal stepped solar still: Experimental and numerical analysis, Desalination, Volume 441, 2018, Pages 8795, ISSN 0011-9164,

24. Braun, Reiner \& Haag, Maximilian \& Stave, Jonas \& Abdelnour, Nermeen \& Eicker, Ursula. (2019). System design and feasibility of trigeneration systems with hybrid photovoltaic-thermal (PVT) collectors for zero energy office buildings in different climates. Solar Energy. 196. 39. 10.1016/j.solener.2019.12.005.

25. Wolf M. Performance analyses of combined heating and photovoltaic power systems for residences. Energy Conversion, 16, 1976, p.79-90.

26. Patrick Dupeyrat, Christophe Ménézo, Harry Wirth, Matthias Rommel, Improvement of PV module optical properties for PV-thermal hybrid collector application, Solar Energy Materials and Solar Cells, Volume 95, Issue 8, 2011, Pages 2028-2036, ISSN 0927-0248,

27. Lee, Joo \& Hwang, Seong \& Lee, Gwi. (2019). Efficiency Improvement of a Photovoltaic Thermal (PVT) System Using Nanofluids. Energies. 12. 3063. 10.3390/en12163063.

28. Bennett Widyolar, Lun Jiang, Jordyn Brinkley, Sai Kiran Hota, Jonathan Ferry, Gerardo Diaz, Roland Winston, Experimental performance of an ultra-lowcost solar photovoltaic-thermal (PVT) collector using aluminum minichannels and nonimaging optics, Applied Energy, Volume 268, 2020, 114894, ISSN 0306-2619. 